\title{
A comparative analysis on the hedonic consumption and lifestyle of voluntary simplicity behaviors of gastronomy tourists
}

Gürkan Akdăg*, Şule Demir

\author{
ABSTRACT
}

Keywords:

Lifestyle of Voluntary Simplicity,

Hedonic Consumption, Gastronomy Tourist

Article History:

Submitted: 09.09.2020

Accepted: 22.03 .2021

\begin{abstract}
This study primarily seeks to identify the reasons of the hedonic consumption of gastronomy tourists and to explore their lifestyle of voluntary simplicity. It also aims to determine the correlation between the reasons of hedonic consumption and lifestyle of voluntary simplicity behaviours, and demographic variables. The study population consists of gastronomy tourists who visited Istanbul, Turkey in 2019. The data were collected from local gastronomy tourists who visited Istanbul between February, 20th and March 10th, 2019 and had gastronomy experiences during their visits based on purposeful sampling method. Accordingly, the study analyzed the data obtained from 440 surveys through loss data analysis, multi-slope analysis, multiple normal distribution tests. The data were examined using descriptive statistics as well as factor, t-test, ANOVA and correlation analyses. The reasons of the hedonic consumption of the gastronomy tourists were identified as consumption for togetherness, consumption for having an idea, consumption for relaxing, consumption for having an adventure and consumption for creating value. On the other hand, the lifestyle of voluntary simplicity was grouped under the dimensions of conscious purchasing behaviour, desire for self-sufficiency, durability of products, desire for simple products and desire for a comfortable life. The study lastly carried out analyses on the correlation between the reasons of the hedonic consumption and the lifestyle of voluntary simplicity trends. It consequently reported statistically significant findings between the reasons of the hedonic consumption and the lifestyle of voluntary simplicity behaviours.
\end{abstract}

Doi: https://doi.org/10.31822/jomat.808175

\section{Introduction}

Today, the concept of consumption has gone beyond just being an act of purchasing to meet the needs of individuals as it has become a phenomenon where consumers enjoy having a product or service even if they do not need it. Consumers only desire to feel pleasure and happiness with the product or service they purchase, and they are involved in consumption for such purpose. After a while, the act of consumption becomes insufficient for consumers and they repeat this act to experience the same pleasure more intensely. Consumers may perform the act of consumption to make their loved ones happy, to socialize, to learn about the sales in the market, to have an adventure, and to get rid of the stress of daily life.
With the enumeration of acts of consumption, a lifestyle of voluntary simplicity, which espouses simplicity in all aspects of life, started to garner attention. A lifestyle of voluntary simplicity is based on an approach to reduce the consumption of the individual that $\mathrm{s} /$ he does not need or is engaged in an impulsive way. The main motivations of a lifestyle of voluntary simplicity are to enable consumers to desire for simpler products, to produce their own food, to take environmentally friendly actions such as compost and permaculture. Besides all these, individuals internalize this philosophy, embrace a more peaceful and calm mind and act so in all areas of their life; these are the main factors of a lifestyle of voluntary simplicity. This present study seeks to determine the reasons why gastronomic tourists are involved

\footnotetext{
\begin{tabular}{c}
\hline *Corresponding Author \\
\hline Gürkan Akdă̌ : Assoc. Prof. Dr., Mersin University, Tourism Faculty, Department of Gastronomy and Culinary Arts, Mersin, Turkey,
\end{tabular}

Gürkan Akdağ:
Email: gurkanakdag@mersin.edu.tr, Orcid Id:0000-0001-9819-9465 (iD)

Sule Demir. Lect. Karamanoğlu Mehmetbey University, Vocational School of Social Sciences, Karaman, Turkey,

Şule Demir: $\quad$ Email: suledemir@kmu.edu.tr, Orcid Id:0000-0003-4816-7443 (iD
} 
in hedonic consumption, to explore their lifestyles of voluntary simplicity, and to determine whether these two phenomena differ from a demographic perspective; thus, it also aims to add new insights both to the literature and the practical field.

\section{Theoretical Framework}

\section{Gastronomy Tourism and Gastronomy Tourists}

Today tourism activities continue to flourish as leisure time and income of individuals increase. Tourism offers various activities that allow individuals to feel free and creative while getting away from the routine of daily life. Gastronomy tourism is one of the current tourism types, increasingly attracting attention every year and involving more and more people (Georgica et al., 2014). According to Wolf (2006), culinary (gastronomic) tourism is defined as traveling to discover the food and beverages of a destination and to enjoy rare gastronomy experiences (Koçoğlu, 2019). The motivation for gastronomy-based travels was the interest in different culinary cultures started with people wondering about different culinary cultures (Deveci, Türkmen, \& Avcikurt, 2013). Then, gastronomy became associated with tourism and evolved into an indispensable part of the travel experience (Canizares \& Guzman, 2012; Akdağ et al., 2015). Nowadays, gastronomy-driven travels are increasingly popular both on a national and international scale. Through these travels, individuals can both discover new destinations and experience unique tastes and flavours that they have not experienced before. The premise of gastronomic tourism activities is gastronomic tourists. Gastronomy tourists are; individuals whose primary motivation is to have a gastronomic experience and who travel to that end. The differences in tourist preferences and demands in the 21 st century highlight the importance of understanding gastronomic tourists and developing supply elements for the preferences of gastronomic tourists.

\section{Hedonic Consumption}

Pleasure is typically defined as pleasant affection and a feeling of liking, whilst it refers to having spiritual or sensory enjoyment from something from a philosophical perspective (TDK, 2019).Pleasure is a force that pushes all living creatures to action instinctively, and all creatures avoid pain and seek pleasure. Based on this perspective, hedonism considers what gives pleasure "good" and what causes pain "bad"
(Çakmak \& Cakır, 2012). In other words, hedonism is one's sickly indulgence in pleasure and physical enjoyment by acknowledging that the only value of human life and purpose is pleasure and that anything that gives pleasure is good (TDK, 2019).The concept of hedonic consumption, which first emerged from semiotics in the postmodern period and aim at the happiness of an individual, was originally introduced to the literature by Hirschman and Holbrook (1982), and with the increase in the consumption, this concept has attracted the attention of more and more scholars every year. Hedonic consumption is expressed through three different concepts in the literature: fantasy, emotions and multi-sensory dimensions. In another study on hedonic consumption, Arnold and Raynolds (2003) defined hedonic consumption as the dimensions of behaviour related to fantasy and emotional situations that appealed to multiple senses and argued that hedonic consumption plays a paramount role in individuals' lives and choices.

\section{Lifestyle of Voluntary Simplicity}

Voluntary simplicity is an oppositional life strategy that rejects materialistic lifestyles and is often referred to as "the simple life" or "downshifting." This approach, sometimes called "the silent revolution", argues that material needs should be met as simply and directly as possible (Alexander, 2011). Voluntary simplicity is defined as "an externally simple but internally rich lifestyle" (Elgin, 2010).This concept was first introduced to the literature in a philosophical essay by Gandhi's student Gregg (1936). Gregg (1936) defined voluntary simplicity as "singleness of purpose, sincerity and honesty within, as well as avoidance of exterior clutter, of many possessions irrelevant to the chief purpose of life." (Ballantine \& Creery, 2010). The concept of voluntary simplicity was forgotten with the consumption boom after World War II, and there was a renewed interest in this concept after the 1970s (Shama, 1985: Aydın \& Kazançoğlu, 2018). Particularly in the 21st century, the lifestyle of voluntary simplicity, which is an important lifestyle alternative to consumerism, has been favoured by more and more individuals every day.

\section{Methodology}

\section{Research Method}

This study is a descriptive study as it aims to determine the behaviours of hedonic consumption and lifestyle of voluntary simplicity of gastronomy tourists. The study population consists of 
gastronomy tourists who visited Istanbul, Turkey in 2019. The main reason for choosing Istanbul as the study area is that Istanbul's cuisine is a very diverse one, which has been influenced by Jewish, Armenian and Greek cultures, which are mainly inspired by the Ottoman palace cuisine, as well as features Anatolian flavors (Demir et al., 2018). This study drew on the scale for hedonic consumption, developed by Arnold \& Reynolds (2003), to measure the hedonic consumption tendencies of the participants. As for the lifestyle of voluntary simplicity, it used the scale of lifestyle of voluntary simplicity, translated into Turkish by Meto (2017) based on the scale of the lifestyle of voluntary simplicity developed by Iwata (2006). The survey was administered to the local gastronomy tourists visiting Istanbul and having a gastronomic experience on February and March, 2019. These individuals were informed on the subject of the study in the introduction of the survey and asked to fill the survey if they were willing to participate in the study. A total of 440 surveys were obtained and analyzed afterwards to check whether they were correctly and consistently filled. All items in the surveys were answered, and multi-slope analysis and multiple normal distribution tests showed that there was no need to exclude any observation value. The analyses were performed on the data obtained from 440 participants. The 25-item scale for hedonic consumption trends was used to determine the hedonic consumption trends of gastronomy tourists. The Cronbach's Alpha value, that is, the reliability coefficient of this scale was calculated as 0.911 . The second scale used in this study is the $22-$ item scale of lifestyle of voluntary simplicity. The Cronbach's Alpha value of this scale was 0.835 . The Cronbach's Alpha value is a model to indicate homogeneity between the items of a scale. Hair, et al. (2010) reported that internal consistency, which is one of the most frequently used reliability measures following the test-retest method, shows the consistency of a scale as a whole and .70 is the lower bound of the Cronbach's Alpha statistics. According to Kayış (2010), an Alpha value between $0.80<a<1.00$ indicates a highly reliable scale. A factor analysis was carried out with the 22-item scale. The factor analysis was performed to test the construct validity of the scale for reasons of hedonic consumption of gastronomy tourists. The communality values of 2 items were below .500 and excluded from the analysis. The factor analysis on the 25-item scale for hedonic consumption dimensioned the 23-item scale under 5 factors and explained $62.956 \%$ of the total variance. Similarly, a factor analysis was performed to test the construct validity of the scale of lifestyle of voluntary simplicity. The communality values of 6 items were below .500 and excluded from the analysis. The factor analysis on the 22 -item scale for hedonic consumption dimensioned the 16-item scale under 5 factors and explained $66.971 \%$ of the total variance. The data were analyzed through confirmatory factor analysis to determine whether the scale is an accurate measurement tool for the data obtained. The confirmatory factor analysis found the chi-square value as 1449.72 , the df value (degrees of freedom) as 620 as well as the Chi square/df value as 2.33 . The limit value for the Chi square/df value is (3) (Güvenç, 2010, p. 65). It seems that the current data show a good statistical fit. As for the other goodness of fit indicators, the analysis found the value of RMSEA as 0.056, the value of NNFI as 0.95 , the value of CFI as 0.95 and the value of IFI as 0.95 .

\section{Research Questions}

A research question is a research problem through which the researcher seeks to find an answer on a topic. It is essential to develop the research question(s) properly and to establish the connection between the variables well in order to select the accurate population, sample and measurement tools and to carry out analyses correctly. A good research question is an openended question and inquiring unlike a hypothesis (Toy \& Tosunoğlu, 2007: 4).A study can achieve its objectives by answering research questions. Thus, the research questions of this study are as follows:

RQ1: Which factors can be used to examine the hedonic consumption trends of gastronomy tourists?

RQ2: Do the hedonic consumption trends of gastronomy tourists differ depending on their demographic characteristics?

RQ3: Which factors can be used to examine the trends of gastronomy tourists towards a lifestyle of voluntary simplicity?

RQ4: Do the trends of gastronomy tourists towards a lifestyle of voluntary simplicity differ depending on their demographic characteristics?

RQ5: Is there a correlation between the hedonic consumption and lifestyle of voluntary simplicity behaviours of gastronomy tourists? 
Table 1. Distribution of the Demographic Characteristics of the Participants

\begin{tabular}{|c|c|c|c|c|c|}
\hline Characteristic & $\begin{array}{l}\text { Frequency } \\
\text { (n) }\end{array}$ & Percentage (\%) & Characteristic & Frequency (n) & Percentage (\%) \\
\hline \multicolumn{3}{|c|}{ Age } & \multicolumn{3}{|c|}{ Educational Level } \\
\hline Aged between $18-22$ & 77 & 17.5 & $\begin{array}{l}\text { High school } \\
\text { Degree }\end{array}$ & 49 & 11.0 \\
\hline Aged between 23-37 & 279 & 63.4 & $\begin{array}{l}\text { Associate's } \\
\text { Degree }\end{array}$ & 61 & 13.9 \\
\hline Aged 38 or older & 84 & 19.1 & $\begin{array}{l}\text { Undergraduate } \\
\text { Degree }\end{array}$ & 262 & 59.5 \\
\hline Total & 440 & 100 & Graduate Degree & 68 & 15.5 \\
\hline \multicolumn{3}{|c|}{ Gender } & Total & 440 & 100 \\
\hline Female & 292 & 66.4 & \multicolumn{3}{|c|}{ Sector They Work in } \\
\hline Male & 148 & 33.6 & Private Sector & 210 & 47.7 \\
\hline Total & 440 & 100 & Public Sector & 62 & 14.1 \\
\hline \multicolumn{3}{|c|}{ Maritial Status } & Student & 91 & 20.7 \\
\hline Married & 172 & 39.1 & Non-employed & 77 & 15.5 \\
\hline Single & 268 & 60.9 & Total & 440 & 100 \\
\hline Total & 440 & 100 & & & \\
\hline
\end{tabular}

\section{Research Findings}

This study first identified the demographic characteristics of the gastronomy tourists. Table 1 shows the demographic characteristics of the 440 gastronomy tourists who participated in this study by age, gender, civil status, sector they work in and educational level. As seen, $63.4 \%$ of the tourists were aged between 23-37. There were 84 tourists aged between 38-52 or older, which accounted for $19.1 \%$ of the participants. Lastly, 77 of them, that is $17.5 \%$ of the participants, were aged between 18 22.

$66.4 \%$ of the participants $(n=292)$ were female whilst $33.6 \%$ of them $(n=148)$ were male. As for their civil status, a total of 268 gastronomy tourists, which account for $60.9 \%$, were single. On the other hand, 172 , that is $39.1 \%$ of the participants were married. $59.5 \%$ of them $(n=262)$ held an undergraduate degree; $13.9 \%(n=61)$ held an associate's degree; $15.5 \%(n=68)$ held a graduate degree whilst $11.1 \%(n=49)$ held a high school degree. This study also identified the sectors that the gastronomy tourists worked in; 47.7\% $(n=210)$ worked in private sector; $20.7 \% \quad(n=91)$ were students; $15.5 \%(n=77)$ were non-employed and $14.1 \%(\mathrm{n}=62)$ worked in public sector.

\section{Findings on Hedonic Consumption}

An exploratory factor analysis was performed on the scale of hedonic consumption to answer the first research question regarding "the factors that can be used to examine the hedonic consumption trends of gastronomy." The test statistics on the suitability of the factor analysis showed that its Kaiser Mayer Olkin value was good with 90.1 and the Bartlett's test of sphericity was significant as well. In the exploratory factor analysis, the acceptance value for communality and factor load values was set to .50. There were 2 items with a value below the acceptance value (items numbered 9 and 21), which were then removed from the subsequent analyses. The lowest factor loading was 0.516 whilst the highest factor loading was 0.837 . To determine the factor dimensions in the scale of hedonic consumption, this study drew on eigenvalue-based procedure for dimensions. Factors with eigenvalues greater than 1 were included in the analysis. Factors with eigenvalues greater than 1 are considered statistically significant. Consequently, the 23-item scale of hedonic consumption had 5 factors explaining $62.956 \%$ of the variance.

The second research question is "Do the hedonic consumption trends of gastronomy tourists differ depending on their demographic characteristics?" An independent paired sample t-test was performed to determine whether the reasons for hedonic consumption significantly varied by gender. Table 3 presents the results of the t-test. As seen, no significant difference was found in terms of the variable of gender between the scores on the dimensions of consumption for having an idea, consumption for relaxing and consumption for creating value; there was a significant difference between the motivational dimensions of 
Table 2. Factor Analysis on the Scale of Hedonic Consumption

\begin{tabular}{|c|c|c|c|c|c|}
\hline & $\begin{array}{l}\text { Factor } \\
\text { load }\end{array}$ & $\begin{array}{l}\text { Eigen } \\
\text { value }\end{array}$ & $\begin{array}{l}\text { Variance } \\
\text { explained }\end{array}$ & Average & Reliability \\
\hline Consumption for togetherness & & 8.004 & 34.800 & 3.92 & .859 \\
\hline I like to buy different local foods for my loved ones & .745 & & & & \\
\hline $\begin{array}{l}\text { I like to search and find places that offer the best gastronomic experience for my loved } \\
\text { ones }\end{array}$ & .715 & & & & \\
\hline I feel good when I book a good restaurant for my friends and family & .710 & & & & \\
\hline $\begin{array}{l}\text { I like to buy local food and local ingredients from the places I visit for the special people } \\
\text { in my life. }\end{array}$ & .701 & & & & \\
\hline I like to attend food-related activities with my family and friends to socialize & .654 & & & & \\
\hline I like to meet local vendors in the places I visit & .531 & & & & \\
\hline I enjoy talking to my friends about food & .516 & & & & \\
\hline Consumption for having an idea & & 2.211 & 9.615 & 3.00 & .873 \\
\hline I engage in activities to see the new trends in gastronomy. & .812 & & & & \\
\hline I buy gastronomy books to learn about new cuisines & .766 & & & & \\
\hline I travel to experience a new cuisine & .754 & & & & \\
\hline I visit new places to get new food experiences about a gastronomic product & .753 & & & & \\
\hline Consumption for relaxing & & 1.583 & 6.882 & 3.67 & .755 \\
\hline I enjoy consuming a gastronomic product & .759 & & & & \\
\hline In my opinion, visiting a new place to taste local food is the best way to relieve stress & .671 & & & & \\
\hline Participating in food-related activities when I am sad makes me feel better & .669 & & & & \\
\hline I prefer gastronomic products to get rid of the banality of daily life. & .634 & & & & \\
\hline Consumption for having an adventure & & 1.479 & 6.430 & 3.54 & .839 \\
\hline I find foods I have not tried before appealing & .837 & & & & \\
\hline I find it exciting to experience new foods & .802 & & & & \\
\hline When I try a new food, I feel in a world of my own & .729 & & & & \\
\hline While having gastronomic experiences, I get the feeling that I have an adventure. & .519 & & & & \\
\hline Consumption for creating value & & 1.203 & 5,230 & 3.27 & .734 \\
\hline I enjoy bargaining when I buy local food & .779 & & & & \\
\hline When buying a gastronomic product, I try to get the cheapest one & .760 & & & & \\
\hline I like to look for discounts when purchasing a gastronomic product. & .755 & & & & \\
\hline I prefer to eat at affordable restaurants instead of expensive ones & .626 & & & & \\
\hline
\end{tabular}

Source: Authors

consumption for togetherness ( $\mathrm{t}$ value. 2.106 s.d: 438 and $\mathrm{p}<0.05)$ and consumption for having an adventure ( $\mathrm{t}$ value. 2.155 , s.d: 438 and $\mathrm{p}<0.05$ ). The average of the scores given by the female participants to the reasons of hedonic consumption in both motivational dimensions was higher than that of the scores given by the male participants.

An independent paired sample t-test was performed to determine whether the reasons for hedonic consumption significantly varied by civil status. Table 4 presents the results of the t-test. No significant difference was found in terms of the variable of civil status between the scores on the dimensions of consumption for having an idea, consumption for relaxing and consumption for having an adventure and consumption for creating value; there was a significant difference in the motivational dimension of consumption for togetherness ( $t$ value. -1.998 s.d: 438 and $\mathrm{p}<0.05$ ). The average of the scores given by the single participants on the dimension of consumption for togetherness was higher than that of the scores given by the married ones.

Table 3. Results of t-Test on the Dimensions of the Reasons of Hedonic Consumption by Gender

\begin{tabular}{|c|c|c|c|c|c|c|}
\hline Dimensions of Hedonic Consumption & Gender & $\mathrm{N}$ & Average & $\begin{array}{l}\text { Std. } \\
\text { Deviation }\end{array}$ & t-value & Significance \\
\hline \multirow[t]{2}{*}{ Consumption for togetherness } & Female & 292 & 3,982 & ,721 & \multirow[t]{2}{*}{2,106} & \multirow[t]{2}{*}{,036 } \\
\hline & Male & 148 & 3,818 & 860 & & \\
\hline \multirow[t]{2}{*}{ Consumption for having an idea } & Female & 292 & 2,994 & 1,076 & \multirow[t]{2}{*}{,- 158} & \multirow[t]{2}{*}{,872 } \\
\hline & Male & 148 & 3,011 & 1,133 & & \\
\hline \multirow[t]{2}{*}{ Consumption for relaxing } & Female & 292 & 3,713 & ,851 & \multirow[t]{2}{*}{1,271} & \multirow[t]{2}{*}{,205 } \\
\hline & Male & 148 & 3,594 & ,959 & & \\
\hline \multirow[t]{2}{*}{ Consumption for having an adventure } & Female & 292 & 3,613 &, 853 & \multirow[t]{2}{*}{2,155} & \multirow[t]{2}{*}{,028 } \\
\hline & Male & 148 & 3,417 & ,923 & & \\
\hline \multirow[t]{2}{*}{ Consumption for creating value } & Female & 292 & 3,277 &, 852 & \multirow[t]{2}{*}{171} & \multirow[t]{2}{*}{,861 } \\
\hline & Male & 148 & 3,261 & ,929 & & \\
\hline
\end{tabular}


Table 4.Results of t-Test on the Dimensions of the Reasons of Hedonic Consumption by Civil Status

\begin{tabular}{|c|c|c|c|c|c|c|}
\hline Dimensions of Hedonic Consumption & $\begin{array}{l}\text { Civil } \\
\text { status }\end{array}$ & $\mathbf{N}$ & Average & $\begin{array}{l}\text { Std. } \\
\text { deviation }\end{array}$ & t-value & Significance \\
\hline \multirow[t]{2}{*}{ Consumption for togetherness } & Married & 172 & 3,835 & ,745 & \multirow[t]{2}{*}{$-1,998$} & \multirow[t]{2}{*}{,046 } \\
\hline & Single & 268 & 3,986 & ,786 & & \\
\hline \multirow[t]{2}{*}{ Consumption for having an idea } & Married & 172 & 2,909 & 1,081 & \multirow[t]{2}{*}{$-, 1,385$} & \multirow[t]{2}{*}{, 165} \\
\hline & Single & 268 & 3,057 & 1,101 & & \\
\hline \multirow[t]{2}{*}{ Consumption for relaxing } & Married & 172 & 3,643 & ,908 & \multirow[t]{2}{*}{,- 555} & \multirow[t]{2}{*}{, 579} \\
\hline & Single & 268 & 3,692 & 879 & & \\
\hline \multirow[t]{2}{*}{ Consumption for having an adventure } & Married & 172 & 3,459 & 899 & \multirow[t]{2}{*}{$-1,678$} & \multirow[t]{2}{*}{,094 } \\
\hline & Single & 268 & 3,603 & ,866 & & \\
\hline \multirow[t]{2}{*}{ Consumption for creating value } & Married & 172 & 3,236 & 841 & \multirow[t]{2}{*}{,- 674} & \multirow[t]{2}{*}{,501 } \\
\hline & Single & 268 & 3,294 & ,902 & & \\
\hline \multicolumn{7}{|c|}{$\begin{array}{c}\alpha=0,05 ; *: p<0.05 \\
\text { Response categories: } 1: \text { I totally disagree..., 5:I totally agree }\end{array}$} \\
\hline
\end{tabular}

Source: Authors

Table 5 shows the results of one-way analysis of variance (ANOVA) conducted to identify the reasons of hedonic consumption by age group. As seen in Table 5, no statistically significant difference was found at a significance level of $\mathrm{p}<0.05$ between the dimensions of consumption for togetherness and consumption for creating value. On the other hand, there was a significant difference between the average of the scores given by the participants on the dimensions of consumption for having an idea (F: 4.466 and $\mathrm{p}<0.05)$, consumption for relaxing ( $\mathrm{F}: 3.466$ and $\mathrm{p}<0.05$ ), consumption for having an adventure $(F: 3.159$ and $p<0.05)$ by age. There was a correlation between the age groups of 23-37 years (2.8826) and 38-52 years or older (3.1905) in the dimension of consumption for having an idea. It is notable that gastronomy tourists aged between 3852 or older are more willing to consume for having an idea. As for the dimension of consumption for relaxing, there was a correlation between the age groups of 18-22 years (3.8344) and 38-52 years or older (3.4732). It is remarkable that gastronomy

Table 4.Results of t-Test on the Dimensions of the Reasons of Hedonic

\begin{tabular}{|c|c|c|c|c|c|c|}
\hline \multicolumn{7}{|c|}{ Consumption by Civil Status } \\
\hline $\begin{array}{l}\text { Dimensions of } \\
\text { Hedonic } \\
\text { Consumption }\end{array}$ & 䏰 & z & 总 & 兽 & $\frac{\mathscr{g}}{\mathrm{E}}$ & 氖 \\
\hline \multirow{2}{*}{$\begin{array}{l}\text { Consumption for } \\
\text { togetherness }\end{array}$} & Married & 172 & 3.835 & .745 & \multirow[t]{2}{*}{$\begin{array}{l}-1.998 \\
\end{array}$} & .04 \\
\hline & Single & 268 & 3.986 & .786 & & 6 \\
\hline \multirow{2}{*}{$\begin{array}{l}\text { Consumption for } \\
\text { having an idea }\end{array}$} & Married & 172 & 2.909 & 1.081 & \multirow[t]{2}{*}{$-.1 .385$} & .16 \\
\hline & Single & 268 & 3.057 & 1.101 & & 5 \\
\hline \multirow{2}{*}{$\begin{array}{l}\text { Consumption for } \\
\text { relaxing }\end{array}$} & Married & 172 & 3.643 & .908 & \multirow[t]{2}{*}{-.555} & .57 \\
\hline & Single & 268 & 3.692 & .879 & & 9 \\
\hline \multirow{2}{*}{$\begin{array}{l}\text { Consumption for } \\
\text { having an adventure }\end{array}$} & Married & 172 & 3.459 & .899 & \multirow[t]{2}{*}{-1.678} & .09 \\
\hline & Single & 268 & 3.603 & .866 & & 4 \\
\hline \multirow{2}{*}{$\begin{array}{l}\text { Consumption for } \\
\text { creating value }\end{array}$} & Married & 172 & 3.236 & .841 & \multirow[t]{2}{*}{-.674} & .50 \\
\hline & Single & 268 & 3.294 & .902 & & 1 \\
\hline & & b; & $\begin{array}{l}0.05 \\
\text { isagree. }\end{array}$ & $5 . \mathrm{J}$ & & \\
\hline
\end{tabular}

Source: Authors tourists aged between 18-22 are more willing to consume for relaxing. Further, there was a correlation between the age groups of 18-22 years (3.7695) and 23-37 years (3.1905) in the dimension of consumption for having an adventure. It is notable that gastronomy tourists aged between 1822 are more adventurous in their consumptions.

Table 5.The results of the ANOVA Analysis on the Reasons of Hedonic Consumption by Age Groups

\begin{tabular}{|c|c|c|c|c|c|c|}
\hline $\begin{array}{l}\text { Dimensions of } \\
\text { Hedonic } \\
\text { Consumption }\end{array}$ & 莆 & Z & $\frac{8}{4}$ & 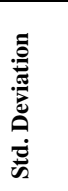 & $\frac{\mathscr{E}}{\mathbb{E}}$ & 异 \\
\hline \multirow{3}{*}{$\begin{array}{l}\text { Consumption } \\
\text { for } \\
\text { togetherness }\end{array}$} & $\begin{array}{l}18- \\
22\end{array}$ & 77 & 4.018 & .797 & \multirow[t]{3}{*}{.857} & \multirow[t]{3}{*}{.425} \\
\hline & $\begin{array}{l}23- \\
37\end{array}$ & 279 & 3.893 & .784 & & \\
\hline & $\begin{array}{l}38- \\
\text { older }\end{array}$ & 87 & 3.955 & .715 & & \\
\hline \multirow{3}{*}{$\begin{array}{l}\text { Consumption } \\
\text { for having an } \\
\text { idea }\end{array}$} & $\begin{array}{l}18- \\
22\end{array}$ & 77 & 3.217 & 1.157 & \multirow[t]{3}{*}{4.466} & \multirow[t]{3}{*}{.012} \\
\hline & $\begin{array}{l}23- \\
37\end{array}$ & 279 & 2.882 & 1.094 & & \\
\hline & $\begin{array}{l}38- \\
\text { older }\end{array}$ & 87 & 3.190 & .986 & & \\
\hline \multirow[t]{3}{*}{$\begin{array}{l}\text { Consumption } \\
\text { for relaxing }\end{array}$} & $\begin{array}{l}18- \\
22\end{array}$ & 77 & 3.834 & .836 & \multirow[t]{3}{*}{3.466} & \multirow[t]{3}{*}{.032} \\
\hline & $\begin{array}{l}23- \\
37 \\
\end{array}$ & 279 & 3.689 & .877 & & \\
\hline & $\begin{array}{l}38- \\
\text { older }\end{array}$ & 87 & 3.473 & .950 & & \\
\hline \multirow{3}{*}{$\begin{array}{l}\text { Consumption } \\
\text { for having an } \\
\text { adventure }\end{array}$} & $\begin{array}{l}18- \\
22 \\
\end{array}$ & 77 & 3.769 & .867 & \multirow[t]{3}{*}{3.159} & \multirow[t]{3}{*}{.043} \\
\hline & $\begin{array}{l}23- \\
37 \\
\end{array}$ & 279 & 3.485 & .860 & & \\
\hline & $\begin{array}{l}38- \\
\text { older }\end{array}$ & 87 & 3.547 & .939 & & \\
\hline \multirow{3}{*}{$\begin{array}{l}\text { Consumption } \\
\text { for creating } \\
\text { value } \\
\end{array}$} & $\begin{array}{l}18- \\
22\end{array}$ & 77 & 3.337 & 1.02 & \multirow[t]{3}{*}{2.153} & \multirow[t]{3}{*}{.117} \\
\hline & $\begin{array}{l}23- \\
37 \\
\end{array}$ & 279 & 3.307 & .856 & & \\
\hline & $\begin{array}{l}38- \\
\text { older }\end{array}$ & 87 & 3.095 & .788 & & \\
\hline
\end{tabular}

Source: Authors 
Journal of multidisciplinary academic tourism 2021, 6 (1): 47-60

Table 6. The results of the ANOVA Analysis on the Reasons of Hedonic Consumption by Sectors

\begin{tabular}{|c|c|c|c|c|c|c|}
\hline $\begin{array}{l}\text { Dimensions of Hedonic } \\
\text { Consumption }\end{array}$ & Profession & $\mathbf{N}$ & Average & $\begin{array}{l}\text { Std. } \\
\text { Deviation }\end{array}$ & f-value & Significance \\
\hline \multirow{4}{*}{ Consumption for togetherness } & Private sector & 210 & 3.971 & .713 & \multirow[t]{4}{*}{1.797} & \multirow[t]{4}{*}{.147} \\
\hline & Public sector & 62 & 3.907 & .736 & & \\
\hline & Student & 91 & 3.989 & .870 & & \\
\hline & Non-employed & 77 & 3.749 & .828 & & \\
\hline \multirow{4}{*}{ Consumption for having an idea } & Private sector & 210 & 3.010 & 1.075 & \multirow[t]{4}{*}{3.124} & \multirow[t]{4}{*}{.026} \\
\hline & Public sector & 62 & 2.959 & 1.105 & & \\
\hline & Student & 91 & 3.236 & 1.108 & & \\
\hline & Non-employed & 77 & 2.724 & 1.075 & & \\
\hline \multirow{4}{*}{ Consumption for relaxing } & Private sector & 210 & 3.679 & .871 & \multirow[t]{4}{*}{2.585} & \multirow[t]{4}{*}{.053} \\
\hline & Public sector & 62 & 3.741 & .870 & & \\
\hline & Student & 91 & 3.807 & .870 & & \\
\hline & Non-employed & 77 & 3.441 & .948 & & \\
\hline \multirow{4}{*}{$\begin{array}{l}\text { Consumption for having an } \\
\text { adventure }\end{array}$} & Private sector & 210 & 3.517 & .874 & \multirow[t]{4}{*}{2.392} & \multirow[t]{4}{*}{.068} \\
\hline & Public sector & 62 & 3.411 & .969 & & \\
\hline & Student & 91 & 3.755 & .839 & & \\
\hline & Non-employed & 77 & 3.490 & .851 & & \\
\hline \multirow{4}{*}{ Consumption for creating value } & Private sector & 210 & 3.196 & .839 & \multirow[t]{4}{*}{1.397} & \multirow[t]{4}{*}{.243} \\
\hline & Public sector & 62 & 3.435 & .774 & & \\
\hline & Student & 91 & 3.277 & 1.001 & & \\
\hline & Non-employed & 77 & 3.340 & .896 & & \\
\hline \multicolumn{7}{|c|}{$\alpha=0,05 ;{ }^{*}: p<0.05$} \\
\hline
\end{tabular}

Table 6 presents the results of one-way analysis of variance on the correlation between the dimensions of the reasons of hedonic consumption and the sector the participants worked in. It further shows that no statistically significant difference was found at a significance level of $\mathrm{p}<0.05$ between the dimensions of consumption for togetherness and consumption for relaxing, consumption for having an adventure and consumption for creating value by the sectors the gastronomy tourists worked in. Yet, there was a significant difference between the average of the scores given by the participants in the dimension of consumption for having an idea (F: 3.124 and $\mathrm{p}<0.05)$ by their sectors. There was a correlation between the groups of students (3.2363) and nonemployed participants (2.7240) in the dimension of consumption for having an idea. It thus follows that students are more willing to consume for having an idea.

\section{Findings on the Lifestyle of Voluntary Simplicity}

An exploratory factor analysis was performed on the scale of lifestyle of voluntary simplicity to answer the third research question regarding "the factors that can be used to examine the trends of gastronomy tourists towards a lifestyle of voluntary simplicity."The test statistics on the suitability of the factor analysis showed that its KMO value was good with 84.3 and the Bartlett's test of sphericity was significant as well. Following the factor analysis, 22 items were examined in terms of communality, factor loads and overlapping (correlation with multiple factors). Items numbered 21, 22, 5, 20 and 18 were excluded from the scale as they were below the threshold value of .50 for communality. The lowest factor loading was 0.501 whilst the highest factor loading was 0.836 . To determine the factor dimensions in the scale of hedonic consumption, this study drew on eigenvalue-based procedure for dimensions. Factors with eigenvalues greater than 1 were included in the analysis. Consequently, the 16 -item scale of lifestyle of voluntary simplicity had 5 factors explaining $66.971 \%$ of the variance. 
Table7. Factor Analysis on the Scale of Lifestyle of Voluntary Simplicity

\begin{tabular}{|c|c|c|c|c|c|}
\hline & $\begin{array}{l}\text { Factor } \\
\text { Load }\end{array}$ & Eigenvalue & Variance & Average & Reliability \\
\hline Conscious Purchasing Behaviour & & 5.315 & 33.222 & 3.543 & .824 \\
\hline Even if I have money. making unplanned purchases is not for me. & .756 & & & & \\
\hline $\begin{array}{l}\text { While shopping. I check whether a product is really necessary for me and } \\
\text { make my decision accordingly. }\end{array}$ & .744 & & & & \\
\hline $\begin{array}{l}\text { I make a list before shopping and do not buy products that are not on my } \\
\text { list. }\end{array}$ & .716 & & & & \\
\hline I try to live a simple life and do not buy products that are not essential. & .715 & & & & \\
\hline $\begin{array}{l}\text { I spend my free time not spending too much money. except the time when } \\
\text { I travel. }\end{array}$ & .676 & & & & \\
\hline $\begin{array}{l}\text { I prefer simple and functional products rather than complex. } \\
\text { multifunctional products. }\end{array}$ & .501 & & & & \\
\hline Desire for Self-Sufficiency & & 1.939 & 12.116 & 4.260 & .765 \\
\hline I would like to pursue a self-sufficient life in the future. & .836 & & & & \\
\hline Self-sufficiency is desired for income-expenditure balance. & .829 & & & & \\
\hline I want to be self-sufficient in food in the future. & .681 & & & & \\
\hline Durability of Products & & 1.252 & 7.824 & 4.093 & .844 \\
\hline I prefer to use a product as long as possible. & .836 & & & & \\
\hline I try to use the products I purchased for as long as possible. & .814 & & & & \\
\hline $\begin{array}{l}\text { While shopping. I seriously consider whether I can use the product for a } \\
\text { long time. }\end{array}$ & .756 & & & & \\
\hline Desire for Simple Products & & 1.131 & 7.067 & 3.448 & .503 \\
\hline Products that offer convenience and comfort spoil people & .769 & & & & \\
\hline I do not buy sophisticated products as much as possible & .737 & & & & \\
\hline Desire for a Comfortable Life & & 1.079 & 6.743 & 3.495 & .377 \\
\hline Material wealth is important to me & .784 & & & & \\
\hline A comfortable life is the most important thing to me & .757 & & & & \\
\hline
\end{tabular}

Source: Authors

The fourth research question is "Do the trends of gastronomy tourists towards a lifestyle of voluntary simplicity differ depending on their demographic characteristics?" An independent paired sample t-test was performed to determine whether the reasons for lifestyle of voluntary simplicity significantly varied by civil status. Table 8 presents the results of the t-test. As seen, no significant difference was found in terms of the variable of civil status between the scores on the dimensions of desire for self-sufficiency, durability of products, desire for simple products and desire for a comfortable life; on the other hand, there was a significant difference in the dimension of conscious purchasing behaviour ( $\mathrm{t}$ value. 2.351 s.d: 395.894 and $\mathrm{p}<0.05$ ). The average of the scores given by the married participants to the trends to the lifestyle of voluntary simplicity in the dimension of conscious purchasing behaviour was higher than that of the scores given by the single participants.

Table 9 presents the results of one way analysis of variance. No statistically significant difference was found at a significance level of $p<0.05$ between the dimensions of conscious purchasing behaviour, desire for self-sufficiency, desire for simple
Table 8.Results of the t-Test on Lifestyle of Voluntary Simplicity by

\begin{tabular}{|c|c|c|c|c|c|c|}
\hline \multicolumn{7}{|c|}{ Civil Status } \\
\hline $\begin{array}{l}\text { Dimensions of } \\
\text { LVS }\end{array}$ & 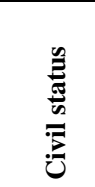 & $\mathbf{Z}$ & 总 & 总 & 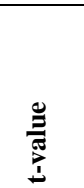 & סू: \\
\hline \multirow{2}{*}{$\begin{array}{l}\text { Conscious } \\
\text { Purchasing } \\
\text { Behaviour }\end{array}$} & Married & 172 & 3.656 & .766 & \multirow[t]{2}{*}{2.351} & \multirow[t]{2}{*}{.019} \\
\hline & Single & 268 & 3.470 & .865 & & \\
\hline \multirow{2}{*}{$\begin{array}{l}\text { Desire for Self- } \\
\text { Sufficiency }\end{array}$} & Married & 172 & 4.215 & .772 & \multirow[t]{2}{*}{-1.026} & \multirow[t]{2}{*}{.305} \\
\hline & Single & 268 & 4.289 & .726 & & \\
\hline \multirow{2}{*}{$\begin{array}{l}\text { Durability of } \\
\text { Products }\end{array}$} & Married & 172 & 4.151 & .815 & \multirow[t]{2}{*}{1.124} & \multirow[t]{2}{*}{.262} \\
\hline & Single & 268 & 4.056 & .898 & & \\
\hline \multirow{2}{*}{$\begin{array}{l}\text { Desire for Simple } \\
\text { Products }\end{array}$} & Married & 172 & 3.427 & .881 & \multirow[t]{2}{*}{-.416} & \multirow[t]{2}{*}{.678} \\
\hline & Single & 268 & 3.462 & .863 & & \\
\hline \multirow{2}{*}{$\begin{array}{l}\text { Desire for a } \\
\text { Comfortable Life }\end{array}$} & Married & 172 & 3.409 & .799 & \multirow[t]{2}{*}{-1.685} & \multirow[t]{2}{*}{.093} \\
\hline & Single & 268 & 3.550 & .885 & & \\
\hline
\end{tabular}

Source: Authors

products and desire for a comfortable life. On the other hand, there was a significant difference between the average of the scores given by the participants on the dimension of durability of products (F:5.234 and $\mathrm{p}<0.05)$ by educational level. There was a correlation between the groups of 
Journal of multidisciplinary academic tourism 2021, 6 (1): 47-60

Table 9.Results of ANOVA on the Dimensions of Lifestyle of Voluntary Simplicity by Educational Level.

\begin{tabular}{|c|c|c|c|c|c|c|}
\hline Dimensions of LVS & Educational Level & $\mathbf{N}$ & Average & Std. Deviation & f-value & Significance \\
\hline \multirow{4}{*}{ Conscious Purchasing Behaviou } & High school Degree & 49 & 3.615 & .917 & \multirow{4}{*}{1.555} & \multirow{4}{*}{200} \\
\hline & Associate's Degree & 61 & 3.434 & .804 & & \\
\hline & Undergraduate Degree & 262 & 3.510 & .807 & & \\
\hline & Graduate Degree & 68 & 3.713 & 876 & & \\
\hline \multirow{4}{*}{ Desire for Self-Sufficiency } & High school Degree & 49 & 4.299 & .755 & \multirow{4}{*}{1.361} & \multirow{4}{*}{.254} \\
\hline & Associate's Degree & 61 & 4.136 & .863 & & \\
\hline & Undergraduate Degree & 262 & 4.307 & .698 & & \\
\hline & Graduate Degree & 68 & 4.161 & 790 & & \\
\hline \multirow{4}{*}{ Durability of Products } & High school Degree & 49 & 3.966 & 1.002 & \multirow{4}{*}{5.234} & \multirow{4}{*}{.001} \\
\hline & Associate's Degree & 61 & 3.732 & .973 & & \\
\hline & Undergraduate Degree & 262 & 4.162 & .797 & & \\
\hline & Graduate Degree & 68 & 4.240 & .844 & & \\
\hline \multirow{4}{*}{ Desire for Simple Products } & High school Degree & 49 & 3.622 & .987 & \multirow{4}{*}{1.041} & \multirow{4}{*}{374} \\
\hline & \begin{tabular}{|l|} 
Associate's Degree \\
\end{tabular} & 61 & 3.500 & .899 & & \\
\hline & Undergraduate Degree & 262 & 3.429 & .819 & & \\
\hline & Graduate Degree & 68 & 3.352 & .938 & & \\
\hline \multirow{4}{*}{ Desire for a Comfortable Life } & High school Degree & 49 & 3.408 & 944 & \multirow{4}{*}{949} & \multirow{4}{*}{417} \\
\hline & Associate's Degree & 61 & 3.434 & .910 & & \\
\hline & Undergraduate Degree & 262 & 3.551 & 829 & & \\
\hline & Graduate Degree & 68 & 3.397 & .835 & & \\
\hline
\end{tabular}

Source: Authors

associate's degree holders (3,7322), undergraduate degree holders (4.1628) and graduate degree holders (4.2402) in the dimension of durability of products. It follows that the gastronomy tourists who held a graduate degree are after the durability of products more than others. Also, no significant correlation was found between the dimensions of lifestyle of voluntary simplicity and the variables of age, income and sector.

\section{Findings on Hedonic Consumption of Lifestyle of Voluntary Simplicity}

The last research question is intended to identify whether there is a correlation between the hedonic consumption and lifestyle of voluntary simplicity of the gastronomy tourists. To that end, a correlation analysis was performed to identify the correlations between the dimensions of the scales used in this study. Table 10 shows the correlation matrix of the dimensions of hedonic consumption, which are CFT, CFHAI, CFR, CFHAA, CFCV, and the dimensions of lifestyle of voluntary simplicity, which are CPB, DFSS, DOP, DFSP, DFACL.

As seen from Table 10, there is a positive and significant correlation between the dimension of "consumption for togetherness", and the dimension of "consumption for having an idea" ( $\mathrm{r}$ : .540; $\mathrm{p}<0.01$ ), the dimension of "consumption for relaxing" $(\mathrm{r}:, 589 ; \mathrm{p}<0.01)$, the dimension of "consumption for having an adventure" $(\mathrm{r}$ : ,524; $\mathrm{p}<0.01$ ), the dimension of "consumption for creating value" $(\mathrm{r}: .268 ; \mathrm{p}<0.01)$, the dimension of "desire for self-sufficiency"(r: .244; $\mathrm{p}<0.01)$, the dimension of "durability of products" ( $\mathrm{r}: .157$; $\mathrm{p}<0.01$ )and "desire for a comfortable life." ( $r: .240$; $\mathrm{p}<0.01)$

Also, the dimension of consumption for togetherness had a moderate-level correlation with consumption for having an idea, consumption for relaxing and consumption for having an adventure; the dimension of consumption for creating value had a low-level correlation with the dimensions of desire for self-sufficiency, durability of products and desire for a comfortable life. That is, as the consumption of the gastronomy tourists for togetherness increases, their consumption for relaxing, having an adventure, creating value will increase, so do their desire for self-sufficiency, durability of products and desire for a comfortable life. However, there was no significant correlation between the dimension of "consumption for togetherness", and the dimension of "conscious purchasing behaviour" $(\mathrm{r}:-.020 ; \mathrm{p}=.673)$ and the dimension of "desire for simple products" ( $r: 0.53$; $\mathrm{p}=.268)$.

This study further identified a statistically significant and positive correlation between the dimension of "consumption for having an idea" and the dimension of "consumption for togetherness" ( $r$ : $.540 ; \mathrm{p}<0.01)$, the dimension of "consumption for relaxing" ( $r: .481 ; p<0.01)$, the dimension of "consumption for having an adventure" ( $\mathrm{r}$ : .523; $\mathrm{p}<0.01$ ) and the dimension of "consumption for creating value" $(\mathrm{r}: .113 ; \mathrm{p}<0.01)$. Yet, it is notable that it had a low-level correlation with the 
dimension of consumption for creating value. That is, as the consumption of the gastronomy tourists for having an idea increases, their consumption for togetherness, relaxing, having an adventure and creating value increases as well. Moreover, there was a negative, low-level, albeit significant, correlation between the dimension of "consumption for creating value" and "conscious purchasing behaviour" ( $\mathrm{r}:-.115 ; \mathrm{p}<0.05)$. In other words, as the consumption of the gastronomy tourists for having an idea increases, their conscious purchasing behaviours will decrease or vice versa. As for other dimensions, no statistically significant correlation was identified between the dimension of "consumption for having an idea", and the dimension of "self-sufficiency" ( $r: 0.46 ; p=.340)$, the dimension of "durability of products" ( $r$ : .010; $=834)$, the dimension of "desire for simple products" $(\mathrm{r}:-.20 ; \mathrm{p}=.675)$ and the dimension of "desire for $\mathrm{a}$ comfortable life" $(r: 0.67 ; p=.161)$.

The dimension of "consumption for relaxing" had a statistically significant and positive correlation with the dimension of "consumption for togetherness" $(r: .589 ; \mathrm{p}<0.01)$, the dimension of "consumption for having an idea" ( $\mathrm{r}: .481 ; \mathrm{p}<0.01)$, the dimension of "consumption for having an adventure" ( $\mathrm{r}: .559 ; \mathrm{p}<0.01)$, the dimension of "consumption for creating value" $(r: .237 ; p<0.01)$, the dimension of "desire for self-sufficiency" ( $r$ : $.106 ; \mathrm{p}<0.05)$ and the dimension of "desire for a comfortable life" ( $r: .197 ; \mathrm{p}<0.01)$. On the other hand, this study identified a moderate-level correlation of the dimension of consumption for togetherness with the dimensions of consumption for having an idea and consumption for having an adventure. A low-level correlation was found between consumption for creating value, and desire for self-sufficiency and desire for a comfortable life. Thus, as the consumption of the gastronomy tourists for relaxing increases, their consumption for togetherness, having an idea, having an adventure and creating value increases as well, so do their desire for self-sufficiency and desire for a comfortable life. Nevertheless, no significant correlation existed between the dimension of "consumption for relaxing", and the dimension of "conscious purchasing behaviour" ( $r$ :,082; $\mathrm{p}=.085$ ), the dimension of "durability of products" $(\mathrm{r}: 0.69 ; \mathrm{p}=.151)$ and the dimension of "desire for simple products" ( $r: 0.47 ; p=.324)$.

The dimension of "consumption for having an adventure" had a statistically significant and positive correlation with the dimension of "consumption for togetherness" ( $r: .524 ; \mathrm{p}<0.01)$, the dimension of "consumption for having an idea" ( $\mathrm{r}: .523 ; \mathrm{p}<0.01)$, the dimension of "consumption for relaxing" $(\mathrm{r}: .559 ; \mathrm{p}<0.01)$, the dimension of "consumption for creating value" $(\mathrm{r}: .160 ; \mathrm{p}<0.05)$, the dimension of "desire for self-sufficiency" ( $r$ : $.105 ; \mathrm{p}<0.05$ ) and the dimension of "desire for a comfortable life" $(r: .141 ; \mathrm{p}<0.01)$. On the other hand, the dimension of consumption for having an adventure had a moderate-level correlation with the dimensions of consumption for togetherness, for having an idea and for relaxing and a low-level correlation with desire for self-sufficiency and desire for a comfortable life. Thus, as the consumption of the gastronomy tourists for having an adventure increases, their consumption for togetherness, having an idea, relaxing and creating value increases as well, so do their desire for selfsufficiency and desire for a comfortable life. Moreover, there was a negative, low-level, albeit significant, correlation between the dimension of "consumption for having an adventure" and "conscious purchasing behaviour" ( $\mathrm{r}$ : - .140; $\mathrm{p}<0.01)$. In other words, as the consumption of the gastronomy tourists for having an adventure increases, their conscious purchasing behaviours will decrease. No significant correlation was found between the dimension of "consumption for having an adventure" and the dimensions of "durability of products" ( $\mathrm{r}: 0.61 ; \mathrm{p}=.201)$ and "desire for simple products" ( $r$ : $-.007 ; \mathrm{p}=.886)$. The dimension of "consumption for creating value", which is one of the dimensions of hedonic consumption, had a lowlevel, positive, albeit significant, correlation with the dimensions of "consumption for togetherness" ( $\mathrm{r}: .268 ; \mathrm{p}<0.01)$, "consumption for having an idea" $(\mathrm{r}: .113 ; \mathrm{p}<0.01)$, "consumption for relaxing" $(\mathrm{r}$ : $.237 ; \mathrm{p}<0.01$ ), "consumption for having an adventure" ( $\mathrm{r}: .160 ; \mathrm{p}<0.01)$, "conscious purchasing behaviour" $(\mathrm{r}: .220 ; \mathrm{p}<0.01)$, "desire for selfsufficiency" $(\mathrm{r}:$.158; $\mathrm{p}<0.01)$, "durability of products" ( $\mathrm{r}: .183 ; \mathrm{p}<0.01)$, "desire for simple products" ( $\mathrm{r}: .232 ; \mathrm{p}<0.01)$ and "desire for a comfortable life" $(\mathrm{r}: .141 ; \mathrm{p}<0.01)$. This study concluded that the dimension of consumption for creating value was the only dimension correlated to all dimensions. As the consumption of the tourists for creating value increases, their consumption for togetherness, for having an idea, for relaxing, for having an adventure increases too, so do their conscious purchasing behaviour, desire for self-sufficiency, durability of products, desire for simple products and a comfortable life. 
Journal of multidisciplinary academic tourism 2021, 6 (1): 47-60

Table 10. Findings on the Correlation between Hedonic Consumption and Lifestyle of Voluntary Simplicity

\begin{tabular}{|c|c|c|c|c|c|c|c|c|c|c|}
\hline Continuous Variables & 1 & 2 & 3 & 4 & 5 & 6 & 7 & 8 & 9 & 10 \\
\hline 1 & 1 & $.540^{* *}$ & $.589^{* *}$ & $.524^{* *}$ & $.268^{* *}$ & -.020 & $.244^{* *}$ & $.157^{* *}$ & .053 & $.240^{* *}$ \\
\hline 2 & $.540^{* *}$ & 1 & $.481^{* *}$ & $.523^{* *}$ & $.113^{*}$ & $-.115^{*}$ & .046 & .010 & -.020 & .067 \\
\hline 3 & $.589^{* *}$ & $.481^{* *}$ & 1 & $.559^{* *}$ & $.237^{* *}$ & -.082 & $.106^{*}$ & .069 & .047 & $.197^{* *}$ \\
\hline 4 & $.524^{* *}$ & $.523^{* *}$ & $.559^{* *}$ & 1 & $.160^{* *}$ & $-.140^{* *}$ & $.105^{*}$ & .061 & -.007 & $.141^{* *}$ \\
\hline 5 & $.268^{* *}$ & $.113^{*}$ & $.237^{* *}$ & $.160^{* *}$ & 1 & $.220^{* *}$ & $.158^{* *}$ & $.183^{* * *}$ & $.232^{* *}$ & $.102^{*}$ \\
\hline 6 & -.020 & $-.115^{*}$ & -.082 & $-.140 * *$ & $.220 * *$ & 1 & $.363 * *$ & $.486^{* * *}$ & $.322 * *$ & .015 \\
\hline 7 & $.244 * *$ & .046 & $.106^{*}$ & $.105^{*}$ & $.158 * *$ & $.363 * *$ & 1 & $.480 * *$ & $.326 * *$ & $.164 * *$ \\
\hline 8 & $.157 * *$ & .010 & .069 & .061 & $.183 * *$ & $.486^{* * *}$ & $.480 * *$ & 1 & $.377 * *$ & $.144 * *$ \\
\hline 9 & .053 & -.020 & .047 & -.007 & $.232 * *$ & $.322 * *$ & $.326 * *$ & $.377 * *$ & 1 & $.147 * *$ \\
\hline 10 & $.240 * *$ & .067 & $.197 * *$ & $.141 * *$ & $.102 *$ & .015 & $.164 * *$ & $.144 * *$ & $.147 * *$ & 1 \\
\hline & & $\begin{array}{r}\text { **.Col } \\
\text { *.Corr } \\
\text { esponse }\end{array}$ & tegories: & I totally & $\begin{array}{l}\text { is sigree.. } \\
\text { isanting }\end{array}$ & .. 5:I tot & $\begin{array}{l}0.01 \\
0.05 . \\
\text { ly agree }\end{array}$ & & & \\
\hline
\end{tabular}

Source: Authors

The dimension of "conscious purchasing behaviour", which is one of the dimensions of lifestyle of voluntary simplicity, had a positive and significant correlation with the dimension of "consumption for creating value" ( $r: .220 ; p<0.01)$, the dimension of "desire for self-sufficiency" ( $r: 363$; $\mathrm{p}<0.01$ ), the dimension of "durability of products" $(\mathrm{r}: 486 ; \mathrm{p}<0.01)$ and the dimension of "desire for simple products" $(\mathrm{r}: 322 ; \mathrm{p}<0.01)$. The dimension of conscious purchasing behaviour had a moderatelevel correlation with the dimension of durability of products and low-level correlation with other dimensions. That is, the conscious purchasing behaviours of the tourists increase, their consumption for creating value, desire for selfsufficiency, for durability of products and simple products increase too. However, the dimension of "conscious purchasing behaviour" had a low-level, negative, albeit significant, correlation with the dimension of "consumption for having an idea" $(\mathrm{r}$ : $115 ; \mathrm{p}<0.05)$ and the dimension of "consumption for having an adventure" $(\mathrm{r}:-140 ; \mathrm{p}<0.01)$. Thus, the conscious purchasing behaviours of the gastronomy tourists increase, their consumption for having an idea and having an adventure will increase too. Yet, no significant correlation was identified between the dimension of "conscious purchasing behaviour" and the dimension of "consumption for having an adventure" ( $r$ : .020; $\mathrm{p}=.673$ ) and the dimension of "consumption for relaxing" ( $\mathrm{r}: .082 ; \mathrm{p}=.750)$.

The dimension of "desire for self-sufficiency", which is one of the dimensions of lifestyle of voluntary simplicity, had a positive and significant correlation with the dimension of "consumption for togetherness" ( $r: 244 ; \mathrm{p}<0.01)$, "consumption for relaxing" ( $r: 106 ; p<0.05)$, "consumption for having an adventure" ( $\mathrm{r}: 105 ; \mathrm{p}<0.05)$, "consumption for creating value" ( $\mathrm{r}: 158 ; \mathrm{p}<0.01)$, “conscious purchasing behaviour" ( $\mathrm{r}: 363 ; \mathrm{p}<0.01)$, "durability of products" ( $r: 480 ; p<0.01)$, "desire for simple products" and "desire for a comfortable life" ( $r$ : 164; $\mathrm{p}<0.01)$. Whilst the dimension of desire for selfsufficiency had a moderate-level correlation with the dimension of durability of products, it had a low-level correlation with other dimensions. No significant correlation was identified between "desire for self-sufficiency" and "consumption for having an idea" ( $\mathrm{r}: 0.46 ; \mathrm{p}=340)$. Thus, as the consumption of the gastronomy tourists with increasing desire for self-sufficiency for togetherness, relaxing, having an adventure and creating value increases, their conscious purchasing behaviour, desire for durability of products, simple products and a comfortable life will increase too.

The dimension of "durability of products" had a positive and significant correlation with the dimensions of "consumption for togetherness" ( $r$ : $157 ; \mathrm{p}<0.01)$, "consumption for creating value" $(\mathrm{r}$ : $183 ; \mathrm{p}<0.01)$, "conscious purchasing behaviour" $(r$ : 486; $\mathrm{p}<0.01$ ), "desire for self-sufficiency" ( $r: 480$; $\mathrm{p}<0.01$ ), "desire for simple products" ( $r: 377$; $\mathrm{p}<0.01$ ) and "desire for a comfortable life." While it had a moderate-level correlation with conscious purchasing behaviour and desire for selfsufficiency, it showed a low-correlation with other dimensions. On the other hand, no significant correlation was found between the dimension of "durability of products" and the dimensions of "consumption for having an idea" ( $r: 0.10 ; p=.834)$ and "consumption for relaxing" $(r: 0.69 ; p=.151)$. 
Thus, as the durability of products increases, the consumption of the gastronomy tourists for creating value, their conscious purchasing behaviours and desire for self-sufficiency, simple products and a comfortable life will increase too.

This study revealed a low-level, positive, albeit significant, correlation between the dimension of "desire for simple products" and the dimensions of "consumption for creating value" $(\mathrm{r}: 232 ; \mathrm{p}<0.01)$, "conscious purchasing behaviour" ( $r: 322 ; p<0.01)$, "desire for self-sufficiency" $(r: 326 ; \quad p<0.05)$, "durability of products" ( $\mathrm{r}: 377 ; \mathrm{p}<0.01)$ and "desire for a comfortable life" ( $r: 147 ; p<0.01)$. That is, as the desire of the gastronomy tourists for simple products increases, their consumption for creating value, conscious purchasing behaviours, desire for self-sufficiency, durability of products and desire for a comfortable life will increase too. Further, there was no significant correlation between the dimension of "desire for simple products" and the dimensions of "consumption for togetherness" ( $r$ : $.053 ; \mathrm{p}=.268)$, "consumption for having an idea" ( $\mathrm{r}$ : $.020 ; p=.675)$, "consumption for relaxing" ( $r: 0.47$; $\mathrm{p}=.324)$ and "consumption for creating value." ( $\mathrm{r}$ : .007; $\mathrm{p}=886$ ).

The dimension of "desire for a comfortable life", which is one of the dimensions of lifestyle of voluntary simplicity, had a positive, low-level, albeit significant, correlation with the dimensions of "consumption for togetherness" ( $\mathrm{r}: 240 ; \mathrm{p}<0.01)$, "consumption for relaxing" ( $r: 197 ; p<0.01)$, "consumption for having an adventure" ( $r: 141$; $\mathrm{p}<0.01)$, "consumption for creating value" ( $\mathrm{r}: 102$; $\mathrm{p}<0.05)$, "desire for self-sufficiency" ( $\mathrm{r}$ : 164; $\mathrm{p}<0.01)$, "durability of products" $(\mathrm{r}: 144 ; \mathrm{p}<0.01)$ and "desire for simple products" $(r: 147 ; p<0.01)$. It follows from that as the desire of the gastronomy tourists for a comfortable life increases, their consumptions for relaxing, having an adventure and creating value will increase, so do their desire for self-sufficiency, durability of products and desire for simple products in linear proportion. However, this study found no significant correlation between the dimension of "desire for a comfortable life" and the dimensions of "consumption for having an idea" $(r: 0.67 ; p=, 161)$ and "conscious purchasing behaviour" ( $\mathrm{r}$ : 0.15; $\mathrm{p}=750$ ).

\section{Discussion and Implications}

This study intends to shed light on the hedonic consumption and lifestyle of voluntary simplicity trends of the gastronomy tourists. The findings from the factor analysis are congruent with the findings of earlier studies on hedonic consumption trends (Özgül, 2011; Çakmak and Çakır, 2012; Doğan et al., 2014). Previous studies with different samples and purposes also determined that women demonstrated more hedonic consumption behaviours than men (Aydın, 2010; Kükrer, 2011; Doğan, et al., 2014; Onurlubaş, 2015). This may perhaps result from that men consume based on a rational understanding whereas women see consumption as a tool that satisfies their pleasure, curiosity, socialization and desire to make others happy. This study ascertained that the single participants were more willing to consume for togetherness compared to the married ones. The reason may be that single individuals can spend their income the way they want compared to married individuals. Some studies in the literature confirm that single consumers tend to make hedonic consumption more than married consumers (Doğan, et al., 2014; Özkan, 2017; Ilgaz, 2018). The findings also revealed that single women are more likely to consume for togetherness than married women, which may result from that married women usually spend time with their family and pay more attention to their expenses due to their responsibilities whilst single women have the chance to spend more time with their friends and spend their income the way they want.

Similarly, the findings on the lifestyle of voluntary simplicity of the gastronomy tourists are congruent with the findings of the previous studies in the literature (Özgül, 2011; Aydın and Kazançoğlu, 2017; Bayat and Sezer, 2018; Chang, 2018). This study examined the correlation between the lifestyle of voluntary simplicity and demographic variables and found significant differences in terms of civil status and educational level. For example, regarding the correlation between the lifestyle of voluntary simplicity and the variable of civil status, this study determined that the married gastronomy tourists exhibited more conscious purchasing behaviours than the single ones. A reason for this may be that married individuals, relative to single individuals, are more careful while spending money due to their social status. Regarding the variable of educational level, this study concluded that gastronomy tourists with a graduate degree valued the durability of products more compared to the gastronomy tourists with an associate's degree and undergraduate degree. This may perhaps result from the fact that as the educational level increases, the desire for making more conscious and environmentally-friendly consumption increases too (Craig-Lees and Hill, 2002; Etzioni, 1998; Zavestoski, 2002; Ergen, 2014; Umut, Topuz and Velioğlu, 2015). 
It was further observed that the gastronomy tourists who consumed for having an adventure and for having an idea had low-level conscious purchasing behaviours. Based on the findings, this group of tourists tends to engage in hedonic consumption most. This study also pointed out a positive and significant correlation between the gastronomy tourists with desire for a comfortable life and their consumption for having an adventure, for relaxing and for creating value. It is reasonable to assume that this group consists of gastronomy tourists who like to buy things for their loved ones, love to socialize, get excited about trying new gastronomic products, consume gastronomic products for relaxing and like to bargain. Thus, this group of gastronomy tourists shows hedonic tendencies that value pleasure and materiality. Also, the gastronomy tourists with desire for self-sufficiency appear to be those who love to share gastronomic experiences with their loved ones, enjoy having new gastronomic experiences, make gastronomic consumption to get rid of the stress of daily life, and bargain and look for sales when purchasing gastronomic products.

From the findings of this study, it is possible to make different inferences for practitioners. Local gastronomy tourists who visit Istanbul and have gastronomy experiences value hedonic consumption in their experiences and exhibit behaviours similar to voluntary simplicity as well. For this reason, it is essential for the efficiency of marketing activities that food and beverage operators as well as managers and employees in gastronomy tourism are familiar with the factors of hedonic consumption and lifestyle of voluntary simplicity that affect the gastronomic experiences of tourists, and correctly interpret consumption behaviours. Understanding of the motivations of local tourists towards hedonic consumption and lifestyle of voluntary simplicity will allow practitioners to better understand local tourists with different motivations and tendencies and to develop different marketing strategies. Besides, businesses will be able to diversify their activities to reach out consumers, who act with the motives of both hedonic consumption and lifestyle of voluntary simplicity, and to offer alternatives that appeal to a lifestyle of voluntary simplicity along with hedonic pleasures in their businesses.

This study was carried out with local gastronomy tourists; further studies may include foreign gastronomy tourists based on the same variables. In this way, the findings from local gastronomy tourists can be compared to the findings to be obtained from foreign gastronomy tourists, providing deeper insights into differences and similarities. Moreover, the findings of this study are based on the data obtained in Istanbul. Future studies may be performed in different destinations and might yield different findings.

\section{References}

Akdağ, G., Akgündüz, Y., Güler, O., \& Benli, S. (2015). Bir seyahat motivasyon araci olarak gastronomi: Hatay'ı ziyaret eden yerli turistlerin seyahat motivasyonları, yiyecek-içecek deneyimleri ve seyahat memnuniyetleri üzerine bir araştırma, 1 . Eurisia international tourism congress: Current issues, trends and indicators, 28-30 May, Konya/Turkey, pp:448-464.

Alexander, S. (2011). The voluntary simplicity movement: Reimagining the good life beyond consumer culture. International Journal of Environmental, Cultural, Economic and Social Sustainability, 7(3), 133-150.

Arnold, J. M., \& Reynolds, K. E. (2003). Hedonic shopping motivations. Journal of Retailing, 79, 77-95.

Aydın, H., \& Kazançoğlu, İ. (2017). The relationship between consumption value and voluntary simplicity lifestyle and effect on environmentally responsible. Eurasian Journal of Business and Management, 5(3), 35-47.

Aydın, S. (2010). Hedonik alışverişin cinsiyet, gelir ve yerleşim büyüklügüne göre farklılaşması üzerine bir araştırma. Süleyman Demirel Üniversitesi Íktisadi ve İdari Bilimler Fakültesi Dergisi, 15(3), 435-452.

Ballantine, P. W., \& Creery, S. (2010). The consumption and disposition behaviour of voluntary simplifiers. Journal of Consumer Behaviour, 9(1), 45-56.

Bayat, M., \& Sezer, A. (2018). Bireylerin gönüllü sade yaşam tarzları ve yaşam doyumlarının, geleneksellik değeri açısından değerlendirilmesi: Düzce üniversitesi örneği. $\dot{I}_{S ̧}$ Ahlakı Dergisi, 11, 69-87.

Çakmak, A. Ç., \& Çakır, M. (2012). 12-18 yaş arası gençlerin hedonik tüketim davranışlarının incelenmesi: Kocaeli şehir merkezinde bir araştırma. Tarih Kültür ve Sanat Araştırmaları Dergisi, 4, 171-189.

Canizares, S. M., \& Guzman, L. T. (2012). Gastronomy as a tourism resource: Profile of the culinary tourist, Current Issues in Tourism, 15(3), 229-245

Chang, H. H. (2018). Exploring consumer behavioral predispositions toward voluntary simplicity. Current Psychology, 1-13. 
Craig-Lees, M., \& Hill, C. (2002). Understanding voluntary simplifiers. Psychology \& Marketing,19, 187-210.

Demir, Ş., Akdağ, G., Sormaz, Ü., \& Özata, E. (2018). Sokak lezzetlerinin gastronomik değeri: Istanbul sokak lezzetleri. Güncel Turizm Araştırmaları Dergisi, 2(1), 589-601.

Deveci, B., Türkmen, S., \& Avcıkurt, C. (2013). Kırsal turizm ile gastronomi turizmi ilişkisi: Bigadiç örneği. Uluslararası Sosyal ve Ekonomik Bilimler Dergisi, 3(2), 29-34.

Doğan, G. H., Gürler, Z. A., \& Ağcadağ, D. (2014). Hedonik tüketim alışkanlıkları üzerine etkili faktörlerin değerlendirilmesi: Tokat ili örneği. Uluslararası Sosyal Araştırmalar Dergisi, 7(30), 69-77.

Elgin, D. (2010). Voluntary simplicity. Toward a way of life that is outwardly simple, inwardly rich. U.S.A. Harper; 2nd edition.

Ergen, A. (2014). Maddi değerler, gönüllü sade yaşam biçimi, çevre bilgisi: Sürdürülebilir tüketim davranışı açısından bir araştırma. Unpublished Doctoral Thesis, Marmara Üniversitesi, İstanbul.

Etzioni, A. (1998). Voluntary simplicity, characterization, select psychological implications, and societal, consequences. Journal of Economic Psychology, 19(5), 619-643.

Georgica, G., Petronela, T., \& Puiu, N. (2014). Gastronomic tourism, a new trend for contemporary tourism??, Cactus Tourism Journal, 9 (1),12-21

Gregg, R. (1936). The value of voluntary simplicity. Pendle Hill: Wallingford, PA.

Güvenç, H. (2010). Ders çalışma özyeterlik algısı ölçeği'nin geliştirme çalışması. Yüzüncü $Y_{1}$ Üniversitesi Eğitim Fakültesi Dergisi, đ(1), 59-69.

Hair, J. F., Black, W. J., Babin, B. J., \& Anderson, R. E. (2010). Multivariate data analysis. Upper Saddle River, NJ: Prentice Hall.

Hirschman, E. C., \& Holbrook, M. B. (1982). Hedonic consumption: emerging concepts, methods and propositions. Journal of marketing, 46(3), 92-101.

Ilgaz, M. (2018). Kuşaklar arası hedonik tüketim davranışlarının demografik özelliklere göre farklılıkları: Kastamonu ili merkez ilçesi üzerine bir araştırma. Turkish Journal of Marketing, $3(1), 1-17$.

Iwata, O. (2006). An evaluation of consumerism and lifesttle as correlates of a voluntary simplicity lifestyle. Social Behavior and Personality, 34(5), 557-568.

Kayış, A. (2010). Güvenilirlik analizi (reliability analysis). Kalaycı, S.. (Ed.) SPSS uygulamalı çok değişkenli istatistik teknikleri, içinde (ss. 404409). Ankara: Asil Yayıncılık.

Koçoğlu, C. M. (2019). Yerli turistlerin gastronomi turizmine yönelik tutumlarının demografik özellikler açısından incelenmesi: Gaziantep örneği. Gastroia: Journal of Gastronomy and Travel Research, 3(2),366-380.

Kükrer, Ö. (2011). Üniversite öğrencilerinde hedonik tüketimin cinsiyete göre farklılaşması. Karadeniz Teknik Üniversitesi İetişim Araştırmaları Dergisi, 1, 78-87.

Meto, H. S. (2017). Voluntary simplicity movement: $A$ comparative study amongst generations in Turkey. Unpublished Master's Thesis. Bahçeşehir University, İstanbul.

Onurlubaş, E. (2015). Determining the factors that affect hedonic consumption, Turkish Studies International Periodical fort he Languages, Literature and History of Turkish or Turkic, 10(15), 694.

Özgül, E. (2011). Tüketicilerin sosyo-demografik özelliklerinin hedonic tüketim ve gönüllü sade yaşam tarzları açısından değerlendirilmesi. Ege Akademik Bakış, 11(1), 25-38.

Özkan, B. (2017). Hedonik tüketim, kadınlar ve burçlar. Uluslararası Yönetim Iktisat ve İsletme Dergisi, 13(1), 117-135.

Shama, A. (1985). The voluntary simplicity consumer. Journal of Consumer Marketing, 2(4), 57-63.

TDK. (2019). Haz kavraminın tanımı, http://www.tdk.gov.tr (last accessed: 20. 01. 2019).

Toy, Y. B., \& Tosunoğlu, G. N. (2007). Sosyal bilimler alanındaki araştırmalarda bilimsel araştırma süreci, istatiksel teknikler ve yapılan hatalar. Ticaret ve Turizm Eğitim Fakültesi Dergisi, 1, 120.

Umut, M. Ö., Topuz, Y. V., \& Velioğlu, M. N. (2015). Çöpten geri dönüşüme giden yolda sürdürülebilir tüketiciler. Celal Bayar Ünivesitesi Sosyal Bilimler Dergisi, 13(2), 263-288.

Wolf, E. (2006). Culinary tourism: The hidden harvest. U.S.A. Dubuque, IA: Kendall/Hunt Publishing Company

Zavestoski, S. (2002). The social-psychological bases of Anti-consumption attidutes. Psychology \& Marketing, 19(2), 149-165. 


\title{
INFO PAGE
}

\section{A comparative analysis on the hedonic consumption and lifestyle of voluntary simplicity behaviors of gastronomy tourists}

\begin{abstract}
This study primarily seeks to identify the reasons of the hedonic consumption of gastronomy tourists and to explore their lifestyle of voluntary simplicity. It also aims to determine the correlation between the reasons of hedonic consumption and lifestyle of voluntary simplicity behaviours, and demographic variables. The study population consists of gastronomy tourists who visited Istanbul, Turkey in 2019. The data were collected from local gastronomy tourists who visited Istanbul between February, 20th and March 10th, 2019 and had gastronomy experiences during their visits based on purposeful sampling method. Accordingly, the study analyzed the data obtained from 440 surveys through loss data analysis, multi-slope analysis, multiple normal distribution tests. The data were examined using descriptive statistics as well as factor, t-test, ANOVA and correlation analyses. The reasons of the hedonic consumption of the gastronomy tourists were identified as consumption for togetherness, consumption for having an idea, consumption for relaxing, consumption for having an adventure and consumption for creating value. On the other hand, the lifestyle of voluntary simplicity was grouped under the dimensions of conscious purchasing behaviour, desire for self-sufficiency, durability of products, desire for simple products and desire for a comfortable life. The study lastly carried out analyses on the correlation between the reasons of the hedonic consumption and the lifestyle of voluntary simplicity trends. It consequently reported statistically significant findings between the reasons of the hedonic consumption and the lifestyle of voluntary simplicity behaviours

Keywords: Lifestyle of Voluntary , Simplicity, Hedonic Consumption, Gastronomy Tourist
Kintity behavious
\end{abstract}

\section{Authors}

Author statement: Author(s) declare(s) that All procedures performed in studies involving human participants were in accordance with the ethical standards of the institutional and/or national research committee and with the 1964 Helsinki declaration and its later amendments or comparable ethical standards.

This paper does not required ethics committee report Justification: The data were collected in 2019, ethics committee approval is not required. 